Pollen analysis of honey from north-eastern Croatia

Peludna analiza meda sjeveroistočne Hrvatske

Rašić, S., Štefanić, E., Antunović, S., Jović, J., Kristek, S.

Poljoprivreda/Agriculture

ISSN: 1848-8080 (Online)

ISSN: 1330-7142 (Print)

http://dx.doi.org/10.18047/poljo.24.2.6

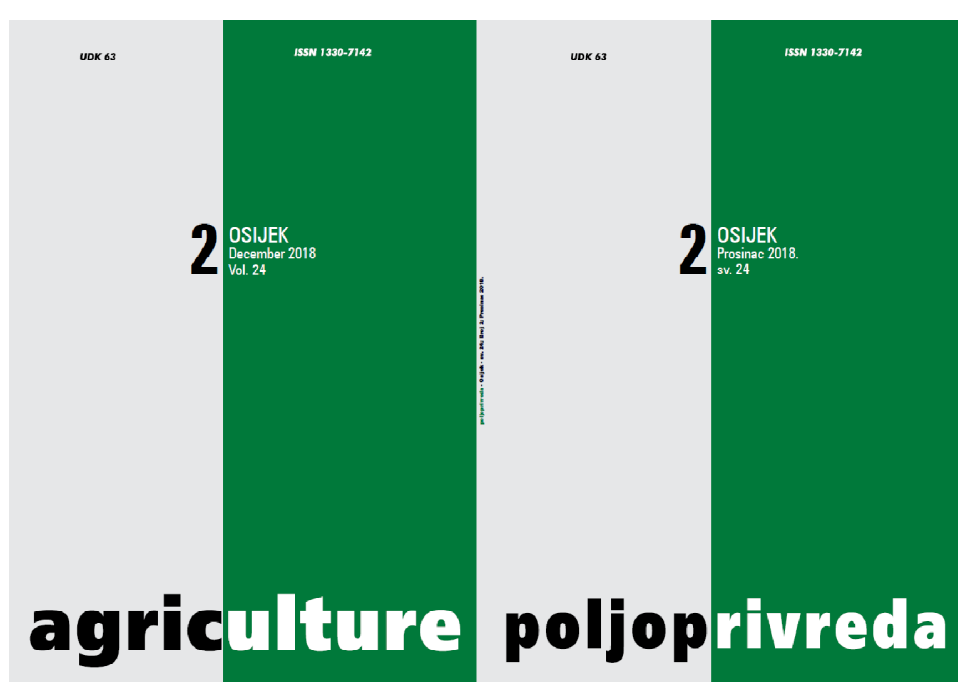

Fakultet agrobiotehničkih znanosti Osijek, Poljoprivredni institut Osijek

Faculty of Agrobiotechnical Sciences Osijek, Agricultural Institute Osijek 
ISSN $1330-7142$

UDK: 638.138:638.14.06-047.44

DOI: $10.18047 /$ poljo.24.2.6

\section{POLLEN ANALYSIS OF HONEY FROM NORTH-EASTERN CROATIA}

Rašić, S. ${ }^{(1)}$, Štefanić, E. ${ }^{(1)}$, Antunović, S. ${ }^{(2)}, J o v i c ́, ~ J .{ }^{(1)}, K r i s t e k, ~ S .(1)$

Original scientific paper

Izvorni znanstveni članak

\section{SUMMARY}

Sixty honey samples from different parts of the north-eastern Croatia were examined for pollen content and pollen share. In total, 84 different pollen grains were identified belonging to 40 families. The most represented families in the honey are: Asteraceae, Fabaceae and Rosaceae. Forty samples are unifloral and twenty are multifloral. Twenty six samples of unifloral honey are from Black locust, twelve from Rapeseed, and two from Lime tree. Honey samples contain 9-25 different types of pollen. Dominant pollen types are Brassicaceae and Robinia pseudacacia.

Key-words: melissopalynological analysis, botanical origin, honey, north-eastern Croatia

\section{INTRODUCTION}

The pollen content of honey reflects regional agricultural practices, forest vegetation and floral diversity of plants. The variability of honey types produced in a region depends on the diversity of nectar source present in the region. The microscopic analysis of honey sediment was the first method used for determining the botanical origin of honey. Pollen analysis was used to determine honey as unifloral or multifloral. The characterization of unifloral honey is necessary for scientific and commercial interests. According to Croatian legislation (Ministry of agriculture, fisheries and rural development, 2009) unifloral honey has at least $45 \%$ its pollen grains deriving from the same plant species. Honey can also be unifloral, if the content of the pollen grains in honey sediment is for example: Tilia spp. $25 \%$, Robinia pseudacacia L. 20\%, Brassica napus var. oleifera DC. $60 \%$. Multifloral honey is a mixture of unifloral one from different species.

Melissopalynological studies are helpful in bee management and in promoting beekeeping development. Botanical properties are important for the honey quality (Ramos et al., 1999; Valencia et al., 2000). Croatia has a long beekeeping tradition, and north-eastern Croatia has favourable climate and vegetation for beekeeping. Most of the beekeepers are semi-professional and keep bee colonies for extra income. The aim of the study is to inform about the results of qualitative melissopalynological analysis honey samples collected in north-eastern Croatia (Osijek-Baranja County, Vukovar-Srijem County). The focus is on the identification of the most important plant source which produced nectar. The knowledge about flora can be of apicultural interest in this area. For this reason, pollen analysis in honey from this part of Croatia, aims at improving their quality and commercialising unifloral honey in order to achieve a higher price in the market.

\section{MATERIAL AND METHODS}

Sixty honey samples were collected from northeastern Croatia (Osijek-Baranja County - 34 samples, Vukovar-Srijem County - 26 samples), directly from beekeepers in 2015. The climate in the north-eastern Croatia is mildly continental with warm, dry summers and cold, snowy winters (Köppen classification - Csb). Meadows, cultivated fields and forests prevail in this area. Forests, which prevail in this area, are Galio-Salicetum alboe, Salici-Populetum nigrae, Carpino betuli-Quercetum roboris, Leucoio-Fraxinetum (Alegro et. al., 2010). Dominant plants in the forest are: R. pseudacacia, Fraxinus spp.,

(1)Assist. Prof. Sanda Rašić (srasic@pfos.hr), Prof. Dr. Edita Štefanić, Prof. Dr. Suzana Kristek, M. Sc. Jurica Jović - Josip Juraj Strossmayer University of Osijek, Faculty of Agrobiotechnical Sciences Osijek, Vladimira Preloga 1, 31000 Osijek, Croatia, (2) Ph. D. Slavica Antunović - Polytechnic in Slavonski Brod, Dr. Mile Budaka 1, 55000 Slavonski Brod, Croatia 
Quercus spp, Salix spp. and Castanea sativa. Amorpfa fruticosa and Rubus spp. can be found in the bush layer. Species from the Poaceae family (Zima and Štefanić, 2009), Daucus carota L., Aster spp., Taraxacum officinale Web., Sinapis spp., Lotus spp., Trifolium repens L., Plantago spp. etc. can be found in the ground layer.

The preparation of honey samples followed the standardized method which was developed and proposed by the International Commission for Bee Botany (Louveaux et al., 1978). This method was validated in 2004 (von der Ohe et al., 2004) and it is widely used. The examination of honey sediment was carried out with an optical microscope at $400 x$ to make identification of the pollen types. Pollen grains were identified with our reference collection and with the relevant literature (von der Ohe, 2003; Bucher et al., 2004). When possible, the pollen grains were identified to species level. The frequency of occurrence denotes the relative amount (\%) of samples in which certain pollen type appeared. Pollen grains were placed into one of the following pollen frequency classes: predominant pollen (more than $45 \%$ of pollen grains content), secondary pollen (16-45\%), important minor pollen (3-15\%), minor pollen (1-3\%) and present pollen ( $\mathrm{p}:<1 \%$ ) (Louveaux et al.,1978). The Shannon-Weaver diversity index (Shannon and Weaver, 1949) was used to calculate the pollen diversity in each sample.

\section{RESULTS AND DISCUSSION}

During this study, 60 honey samples from northeastern Croatia were analysed. A total of 84 pollen types were recorded. These types belong to 40 botanical families. The most represented families are Asteraceae with twelve taxa of pollen grains, Fabaceae with ten and Rosaceae with eight taxa. Brassicaceae, Oleaceae, Fagaceae, Apiaceae and Papaveraceae are represented with three pollen types. Boraginaceae, Chenopodiaceae, Primulaceae, Salicaceae, Betulaceae, Poaceae and Pinaceae are represented with two pollen types. Twenty-five families are represented with only one type. The results are shown in Table 1.

Table 1. Pollen types in honey samples and their frequency

Tablica 1. Vrste peludi u uzorcima meda i njihova učestalost

\begin{tabular}{|c|c|c|c|c|c|c|c|}
\hline $\begin{array}{l}\text { Family } \\
\text { Porodica }\end{array}$ & $\begin{array}{l}\text { Plant species } \\
\text { Biljna vrsta }\end{array}$ & $\mathrm{D}$ & S & IM & $\mathrm{M}$ & $P$ & $\begin{array}{c}\text { Frequency } \\
\text { Učestalost (\%) }\end{array}$ \\
\hline Aceraceae & Acer spp. & 0 & 0 & 0 & 1 & 2 & 3 \\
\hline Apiaceae & $\begin{array}{l}\text { Anthriscus sylvestris } \\
\text { Daucus carota } \\
\text { Heracleum sphondylium }\end{array}$ & $\begin{array}{l}0 \\
0 \\
0\end{array}$ & $\begin{array}{l}0 \\
0 \\
0\end{array}$ & $\begin{array}{l}0 \\
0 \\
0\end{array}$ & $\begin{array}{l}2 \\
6 \\
1\end{array}$ & $\begin{array}{l}5 \\
4 \\
1\end{array}$ & $\begin{array}{r}13 \\
26 \\
1\end{array}$ \\
\hline Asteraceae & $\begin{array}{l}\text { Achillea millefolium } \\
\text { Ambrosia artemisiifolia } \\
\text { Artemisia spp. } \\
\text { Aster spp. } \\
\text { Bellis perenis } \\
\text { Centaurea spp. } \\
\text { Chrysanthemum spp. } \\
\text { Erigeron spp. } \\
\text { Helianthus annuus } \\
\text { Matricaria spp. } \\
\text { Silybum marianum } \\
\text { Taraxacum officinale }\end{array}$ & $\begin{array}{l}0 \\
0 \\
0 \\
0 \\
0 \\
0 \\
0 \\
0 \\
2 \\
0 \\
0 \\
0\end{array}$ & $\begin{array}{l}0 \\
0 \\
0 \\
1 \\
0 \\
0 \\
0 \\
0 \\
7 \\
0 \\
0 \\
0\end{array}$ & $\begin{array}{r}0 \\
0 \\
0 \\
11 \\
0 \\
0 \\
0 \\
0 \\
18 \\
0 \\
0 \\
0\end{array}$ & $\begin{array}{r}3 \\
0 \\
0 \\
23 \\
10 \\
1 \\
1 \\
1 \\
6 \\
1 \\
1 \\
20\end{array}$ & $\begin{array}{l}4 \\
1 \\
2 \\
5 \\
6 \\
2 \\
0 \\
0 \\
6 \\
0 \\
2 \\
5\end{array}$ & $\begin{array}{r}11 \\
1 \\
5 \\
70 \\
26 \\
5 \\
1 \\
3 \\
65 \\
1 \\
5 \\
53\end{array}$ \\
\hline Balsaminaceae & Impatiens spp. & 0 & 0 & 0 & 0 & 1 & 1 \\
\hline Betulaceae & $\begin{array}{l}\text { Alnus spp. } \\
\text { Betula pendula }\end{array}$ & $\begin{array}{l}0 \\
0\end{array}$ & $\begin{array}{l}0 \\
0\end{array}$ & $\begin{array}{l}0 \\
0\end{array}$ & $\begin{array}{l}0 \\
0\end{array}$ & $\begin{array}{l}5 \\
1\end{array}$ & $\begin{array}{l}8 \\
1\end{array}$ \\
\hline Boraginaceae & $\begin{array}{l}\text { Anchusa spp. } \\
\text { Symphytum officinale }\end{array}$ & $\begin{array}{l}0 \\
0\end{array}$ & $\begin{array}{l}0 \\
0\end{array}$ & $\begin{array}{l}0 \\
0\end{array}$ & $\begin{array}{l}0 \\
0\end{array}$ & $\begin{array}{l}1 \\
3\end{array}$ & $\begin{array}{l}1 \\
3\end{array}$ \\
\hline Brassicaceae & $\begin{array}{l}\text { Brassica napus ssp. oleifera } \\
\text { Raphanus spp. } \\
\text { Sinapis spp. }\end{array}$ & $\begin{array}{r}24 \\
0 \\
0\end{array}$ & $\begin{array}{r}13 \\
0 \\
0\end{array}$ & $\begin{array}{r}13 \\
0 \\
5\end{array}$ & $\begin{array}{r}6 \\
0 \\
15\end{array}$ & $\begin{array}{l}0 \\
3 \\
1\end{array}$ & $\begin{array}{r}93 \\
5 \\
38\end{array}$ \\
\hline Caprifoliaceae & Sambucus spp. & 0 & 0 & 0 & 3 & 0 & 5 \\
\hline Caryophyllaceae & Lychnis spp. & 0 & 0 & 0 & 0 & 2 & 3 \\
\hline Chenopodiaceae & $\begin{array}{l}\text { Atriplex spp. } \\
\text { Chenopodium spp. }\end{array}$ & $\begin{array}{l}0 \\
0\end{array}$ & $\begin{array}{l}0 \\
0\end{array}$ & $\begin{array}{l}0 \\
0\end{array}$ & $\begin{array}{l}0 \\
1\end{array}$ & $\begin{array}{l}1 \\
1\end{array}$ & $\begin{array}{l}1 \\
3\end{array}$ \\
\hline Cornaceae & Cornus spp. & 0 & 0 & 0 & 0 & 1 & 1 \\
\hline Cupressaceae & Juniperus spp. & 0 & 0 & 0 & 0 & 2 & 5 \\
\hline
\end{tabular}




\begin{tabular}{|c|c|c|c|c|c|c|c|}
\hline $\begin{array}{l}\text { Family } \\
\text { Porodica }\end{array}$ & $\begin{array}{l}\text { Plant species } \\
\text { Biljna vrsta }\end{array}$ & $\mathrm{D}$ & $S$ & $\mathrm{IM}$ & M & $P$ & $\begin{array}{c}\text { Frequency } \\
\text { Učestalost (\%) }\end{array}$ \\
\hline Cyperaceae & Carex spp. & 0 & 0 & 0 & 0 & 3 & 5 \\
\hline Ericaceae & Erica spp. & 0 & 0 & 0 & 0 & 1 & 1 \\
\hline Fabaceae & $\begin{array}{l}\text { Amorpha fruticosa } \\
\text { Lotus spp. } \\
\text { Medicago spp. } \\
\text { Melilotus spp. } \\
\text { Ononis spp. } \\
\text { Robinia pseudacacia } \\
\text { Trifolium incarnatum } \\
\text { Trifolium pratense } \\
\text { Trifolium repens } \\
\text { Vicia spp. }\end{array}$ & $\begin{array}{r}0 \\
0 \\
0 \\
0 \\
0 \\
10 \\
0 \\
0 \\
0 \\
0\end{array}$ & $\begin{array}{r}2 \\
0 \\
0 \\
0 \\
0 \\
24 \\
0 \\
0 \\
0 \\
0\end{array}$ & $\begin{array}{r}23 \\
1 \\
0 \\
0 \\
0 \\
21 \\
0 \\
0 \\
1 \\
0\end{array}$ & $\begin{array}{r}14 \\
13 \\
1 \\
0 \\
0 \\
4 \\
1 \\
12 \\
27 \\
0\end{array}$ & $\begin{array}{l}4 \\
4 \\
2 \\
1 \\
1 \\
0 \\
1 \\
4 \\
4 \\
1\end{array}$ & $\begin{array}{r}71 \\
30 \\
6 \\
1 \\
1 \\
98 \\
3 \\
30 \\
56 \\
1\end{array}$ \\
\hline Fagaceae & $\begin{array}{l}\text { Castanea sativa } \\
\text { Fagus spp. } \\
\text { Quercus spp. }\end{array}$ & $\begin{array}{l}0 \\
0 \\
0\end{array}$ & $\begin{array}{l}3 \\
0 \\
0 \\
\end{array}$ & $\begin{array}{l}0 \\
5 \\
2\end{array}$ & $\begin{array}{r}6 \\
1 \\
23 \\
\end{array}$ & $\begin{array}{r}7 \\
8 \\
16 \\
\end{array}$ & $\begin{array}{l}26 \\
25 \\
73 \\
\end{array}$ \\
\hline Hippocastanaceae & Aesculus hippocastanum & 0 & 0 & 0 & 3 & 1 & 6 \\
\hline Hydrophyllaceae & Phacelia tanacetifolia & 0 & 0 & 1 & 0 & 1 & 3 \\
\hline Juglandaceae & Juglans regia & 0 & 0 & 2 & 7 & 1 & 16 \\
\hline Lamiaceae & Salvia spp. & 0 & 0 & 0 & 2 & 3 & 10 \\
\hline Liliaceae & Aspagarus spp. & 0 & 0 & 0 & 0 & 1 & 1 \\
\hline Loranthaceae & Loranthus europaeus & 0 & 0 & 0 & 0 & 1 & 1 \\
\hline Moraceae & Morus spp. & 0 & 0 & 0 & 8 & 7 & 23 \\
\hline Oleaceae & $\begin{array}{l}\text { Fraxinus spp. } \\
\text { Ligustrum spp. } \\
\text { Syringa vulgaris }\end{array}$ & $\begin{array}{l}0 \\
0 \\
0\end{array}$ & $\begin{array}{l}1 \\
0 \\
0 \\
\end{array}$ & $\begin{array}{r}27 \\
0 \\
0 \\
\end{array}$ & $\begin{array}{r}26 \\
0 \\
1 \\
\end{array}$ & $\begin{array}{l}4 \\
1 \\
2 \\
\end{array}$ & $\begin{array}{r}90 \\
1 \\
5 \\
\end{array}$ \\
\hline Papaveraceae & $\begin{array}{l}\text { Chelidonium majus } \\
\text { Fumaria spp. } \\
\text { Papaver spp. }\end{array}$ & $\begin{array}{l}0 \\
0 \\
0\end{array}$ & $\begin{array}{l}0 \\
0 \\
0 \\
\end{array}$ & $\begin{array}{l}0 \\
0 \\
0\end{array}$ & $\begin{array}{l}0 \\
1 \\
0 \\
\end{array}$ & $\begin{array}{l}1 \\
1 \\
1 \\
\end{array}$ & $\begin{array}{l}1 \\
5 \\
1 \\
\end{array}$ \\
\hline Pinaceae & $\begin{array}{l}\text { Picea spp. } \\
\text { Pinus spp. }\end{array}$ & $\begin{array}{l}0 \\
0\end{array}$ & $\begin{array}{l}0 \\
0\end{array}$ & $\begin{array}{l}0 \\
0\end{array}$ & $\begin{array}{l}1 \\
2 \\
\end{array}$ & $\begin{array}{l}0 \\
3 \\
\end{array}$ & $\begin{array}{r}1 \\
10 \\
\end{array}$ \\
\hline Plantaginaceae & Plantago spp. & 0 & 0 & 0 & 23 & 12 & 58 \\
\hline Poaceae & \begin{tabular}{|l} 
Poaceae \\
Zea mays
\end{tabular} & $\begin{array}{l}0 \\
0 \\
\end{array}$ & $\begin{array}{l}0 \\
0 \\
\end{array}$ & $\begin{array}{l}2 \\
0 \\
\end{array}$ & $\begin{array}{r}43 \\
9 \\
\end{array}$ & $\begin{array}{r}10 \\
5 \\
\end{array}$ & $\begin{array}{l}95 \\
25 \\
\end{array}$ \\
\hline Polygonaceae & Rumex spp. & 0 & 0 & 0 & 0 & 2 & 3 \\
\hline Primulaceae & $\begin{array}{l}\text { Primula spp. } \\
\text { Lysimachia spp. }\end{array}$ & $\begin{array}{l}0 \\
0\end{array}$ & $\begin{array}{l}0 \\
0\end{array}$ & $\begin{array}{l}0 \\
0\end{array}$ & $\begin{array}{l}0 \\
0\end{array}$ & $\begin{array}{l}1 \\
1\end{array}$ & $\begin{array}{l}1 \\
1 \\
\end{array}$ \\
\hline Ranunculaceae & Ranunculus spp. & 0 & 0 & 0 & 0 & 1 & 1 \\
\hline Rosaceae & $\begin{array}{l}\text { Filipendula spp. } \\
\text { Fragaria spp. } \\
\text { Malus spp. } \\
\text { Potentilla spp. } \\
\text { Prunus spp. } \\
\text { Rosa spp. } \\
\text { Rubus spp. } \\
\text { Spirea spp. }\end{array}$ & $\begin{array}{l}0 \\
0 \\
0 \\
0 \\
0 \\
0 \\
0 \\
0\end{array}$ & $\begin{array}{l}0 \\
0 \\
0 \\
0 \\
0 \\
0 \\
0 \\
0\end{array}$ & $\begin{array}{r}0 \\
0 \\
0 \\
0 \\
15 \\
0 \\
0 \\
0\end{array}$ & $\begin{array}{r}5 \\
0 \\
1 \\
0 \\
26 \\
0 \\
1 \\
1\end{array}$ & $\begin{array}{l}2 \\
1 \\
1 \\
1 \\
4 \\
1 \\
3 \\
0\end{array}$ & $\begin{array}{r}13 \\
1 \\
1 \\
1 \\
1 \\
75 \\
1 \\
6 \\
1\end{array}$ \\
\hline Rubiaceae & Gallium spp. & 0 & 0 & 0 & 2 & 6 & 13 \\
\hline Salicaceae & $\begin{array}{l}\text { Populus spp. } \\
\text { Salix spp. }\end{array}$ & $\begin{array}{l}0 \\
0 \\
\end{array}$ & $\begin{array}{l}0 \\
3 \\
\end{array}$ & $\begin{array}{r}0 \\
42 \\
\end{array}$ & $\begin{array}{r}1 \\
12 \\
\end{array}$ & $\begin{array}{l}1 \\
0 \\
\end{array}$ & $\begin{array}{r}6 \\
93 \\
\end{array}$ \\
\hline Saxifragaceae & Ribes spp. & 0 & 0 & 0 & 0 & 1 & 1 \\
\hline Scrophulariaceae & Verbascum spp. & 0 & 0 & 0 & 0 & 1 & 1 \\
\hline Simaroubaceae & Ailanthus altissima & 0 & 0 & 0 & 0 & 2 & 3 \\
\hline Solanaceae & Solanum spp. & 0 & 0 & 0 & 2 & 2 & 3 \\
\hline Taxaceae & Taxus spp. & 0 & 0 & 0 & 0 & 1 & 1 \\
\hline Tiliaceae & Tilia spp. & 1 & 2 & 0 & 3 & 4 & 20 \\
\hline
\end{tabular}

D - predominant pollen (>45\%), S - secondary pollen (16-45\%), IM - important minor pollen (3-15\%), M - minor pollen (1-3\%), P - present pollen $(<1 \%)$, frequency $(\%)$ 
The number of taxa (pollen types), present in each honey sample that has been studied ranged from 9 to 25. The Shannon-Weaver index increases as the species richness increases. The Shannon-Weaver index ranged between 0.75 (sample with 9 taxa) and 2.53 (sample with 25 taxa). None of pollen types was present in all honey samples. Thirty pollen types are found out in only one honey sample. Nectariferous pollen types, which are found in more than $90 \%$ of the honey samples, are: Robinia pseudacacia L. (98\%), Brassica napus ssp. oleifera DC. (93\%) and Salix spp. (93\%) (Figure 1). Pollen types are present with the highest frequencies (Figure 2) between non-nectariferous plants, Fraxinus spp. (90\%) and Poaceae (95\%).

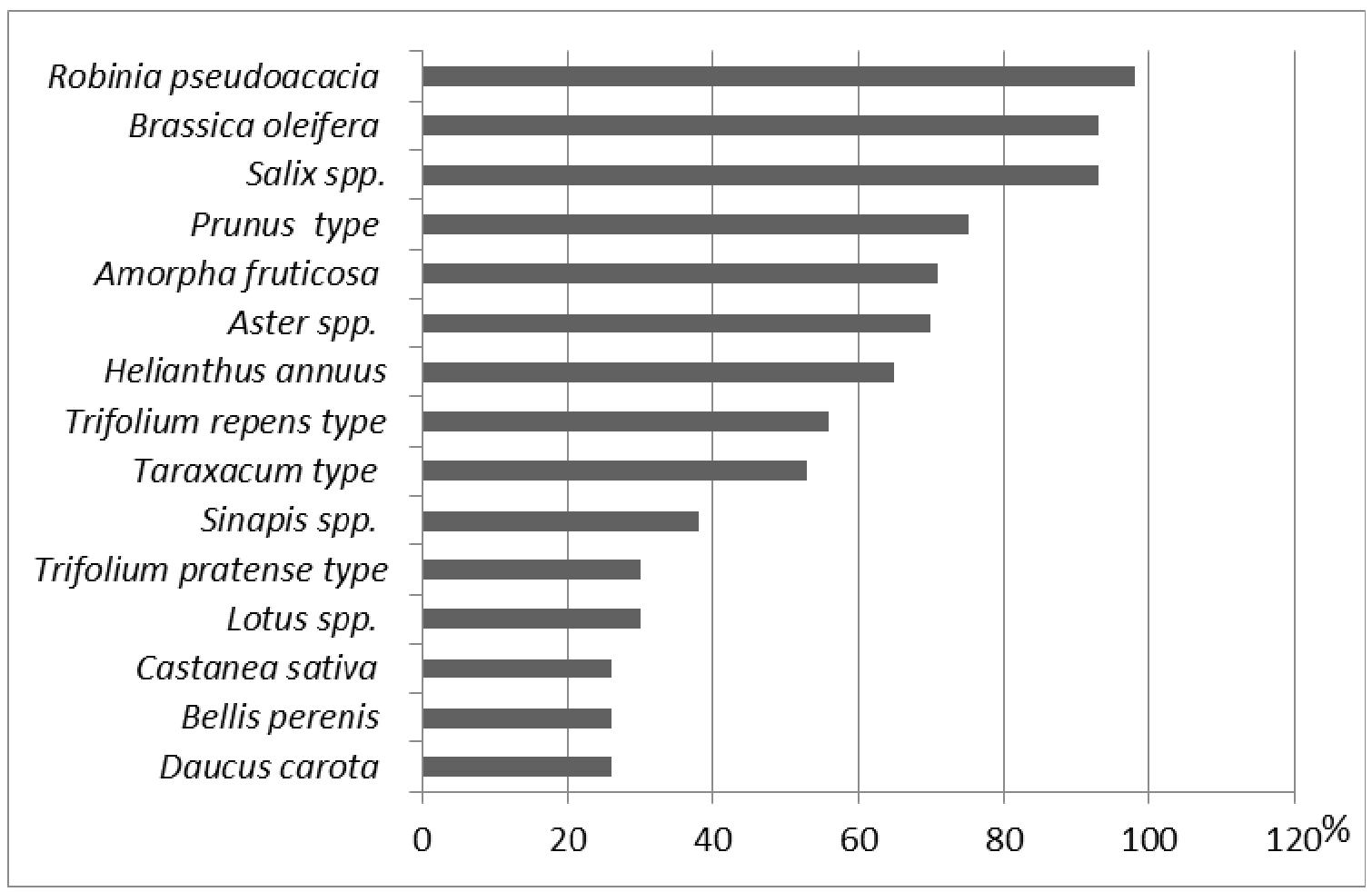

Figure 1. Frequency of occurrence pollen type of nectariferous plants ( $>25 \%$ frequency)

Slika 1. Učestalost pojave peludi nektarnih biljaka (>25\% učestalost)

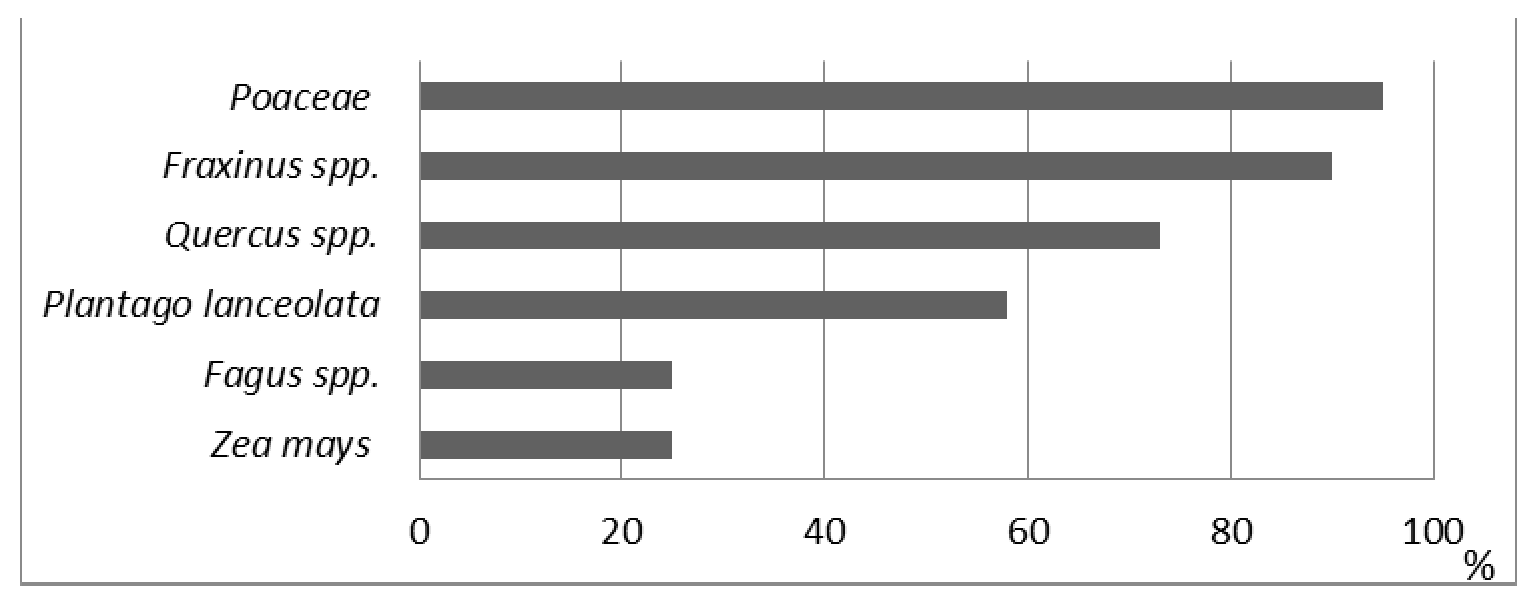

Figure 2. Frequency of occurrence pollen type of non-nectariferous plants ( $>\mathbf{2 5 \%}$ frequency)

Slika 2. Učestalost pojave peludi nenektarnih biljaka (>25\% učestalosti)

The families that occur in more than $50 \%$ of the samples are Fabaceae, found in $95 \%(n=57)$ of the samples, Brassicaceae $83.33 \%(n=50)$ and Salicaceae $68.33 \%(n=41)$ (Figure 3). 


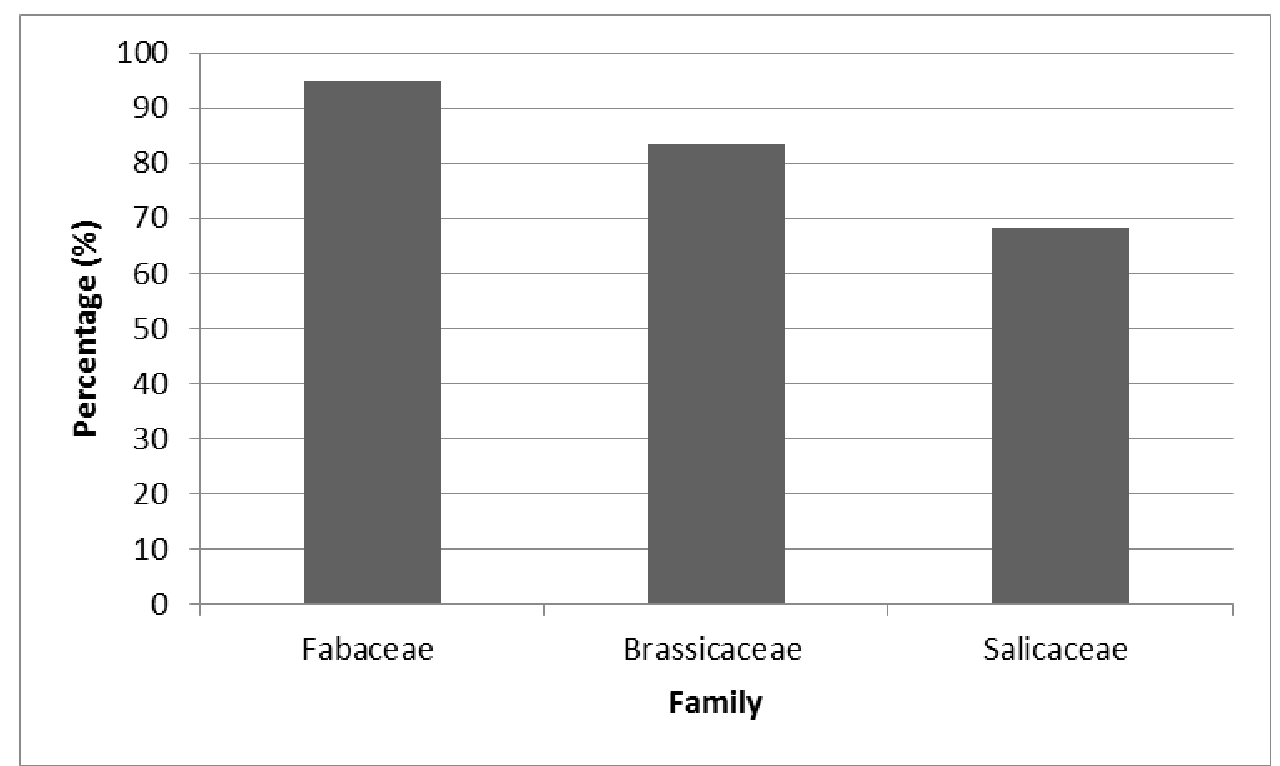

Figure 3. The families found out in more than $\mathbf{5 0 \%}$ of the honey samples

Slika 3. Porodice nađene u više od $50 \%$ uzoraka meda

According to pollen spectra most of the samples (40) are unifloral and 20 samples are multifloral. We found out 26 unifloral Black locust, twelve unifloral rapeseed and two lime tree unifloral samples. The share of unifloral $R$. pseudacacia, Brassica napus ssp. oleifera and Tilia spp. honey were $43.3 \%, 20 \%, 3.3 \%$ whereas the share of multifloral honey type was $33.3 \%$ (Figure 4).

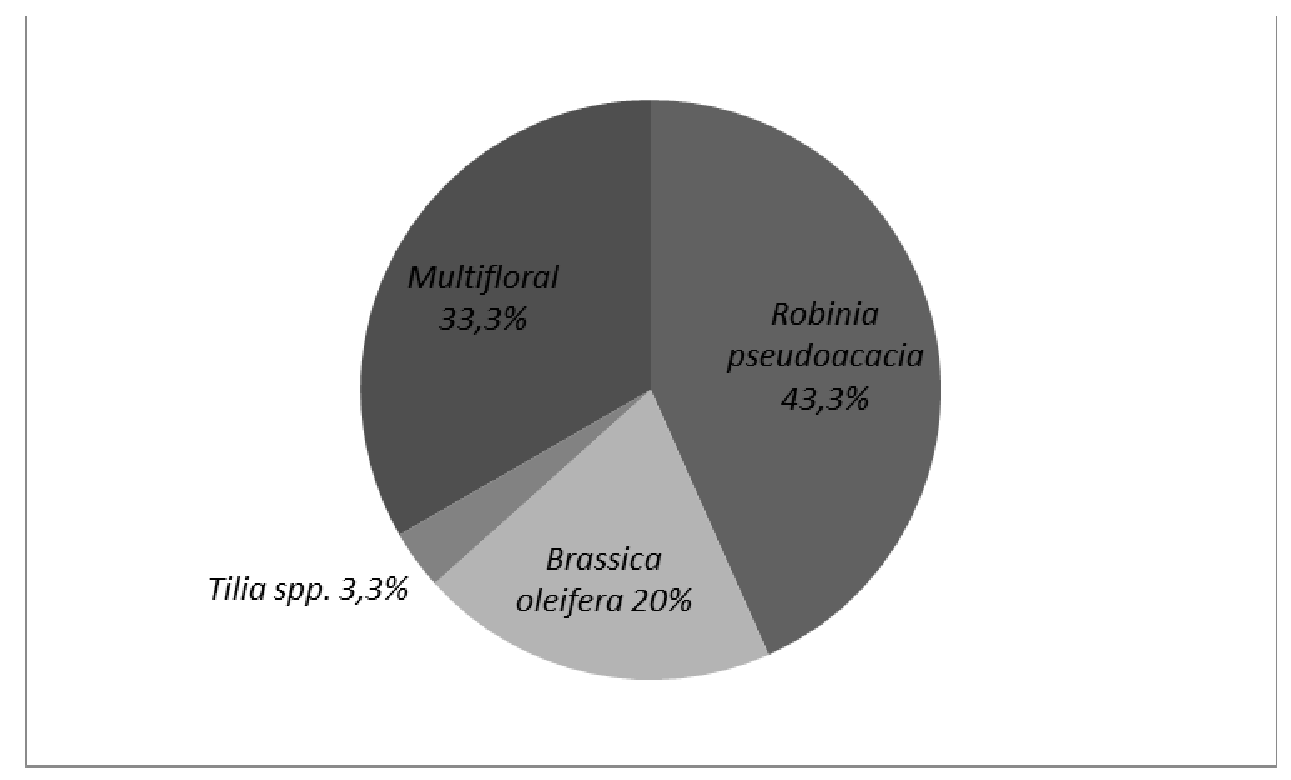

Figure 4. Proportion of different types of honey

Slika 4. Udjeli vrsta meda

Pollen composition of honey is important information on the nectariferous flora of the examination area. The examination describes characteristic flora being a source of nectar flow to honey bees. Pollen grains from dominant and secondary groups are important for honey formation (Kaya et al., 2005). According to the results pollen grains of Brassicaceae family are dominant in 24 honey samples and secondary in 13 honey samples.

Brassicaceae pollen is present in almost all samples $(93 \%)$ and comes from cultivated members of 
the family, such as Brassica napus ssp. oleifera DC. Raphanus raphanistrum L. is present only in three samples (5\%). Pollen type is important In Spanish (Cabrerra-Ruiz et al., 1997) and Anatolia honey (Silici and Gökceoglu, 2007) R. raphanistrum. The members of Brassicaceae families are also frequently observed in honey from Central Anatolia (Sorkun and Yulug, 1985), and in Finland (Salonen et al., 2009). The Brassicaceae are also a valuable nectariferous source in east, central and north-eastern Poland (Wroblewska et al., 2006).

In north-eastern Italy (Gambon et al., 1995), as well as in Greece (Karabournioti et al., 2006) and Croatia (Štefanić et al., 2012) the most frequent occurrence of pollen is provided by plants of the families Asteraceae, Fabaceae and Rosaceae.

Pollen of $R$. pseudacacia, Amorpha fruticosa and Trifolium repens is present in significant amount in analysed honey samples. $R$. pseudacacia is dominant in ten and secondary in 24 honey samples within Fabaceae family. In Hungary (Farkas and Zajacs, 2007) R. pseudacacia is one the most important nectariferous plant. According to Primorac et al. (2008), in southern Croatia contribution of Trifolium spp. pollen in multifloral honey is significant. Štefanić et al. (2005) emphasizes the importance of $A$. fruticosa as nectar flow for honey bees.

Rosaceae family is another important nectariferous source in Croatia. In Ireland, plants of the Rosaceae family are also significant (Coffey and Breen, 1997) so as in Estonia (Puusepp and Koff, 2014).

Alos, plants of Asteraceae family is important nectariferous source in the examination area. Similar results are reported by Terrab et al. (2001). Pollen of Helianthus annus comes in a very significant amount in seven samples, from $16-48 \%$. Some authors consider it as unifloral honey (Perez-Arquillué, 1986). According to Valencia-Barrera et al. (2000), in Leon province (Spain) sunflower honey is as common as in the north-eastern Bulgaria (Shumen region) (Lazarova et al., 2010).

Fraxinus spp. and Salix spp. pollen occurs commonly in honey samples, but never in high proportions. Similarity can be seen in Varaždin County, Croatia as well (Sabo et al., 2011). Pollen of Salix spp. is found out in unifloral and multifloral Lithuanian honey (Čeksteryte et al., 2013).

Poaceae pollen types are present with the highest (95\%) frequencies in north-eastern Croatia; similar is in Finland (Salonen et al., 2009).

\section{CONCLUSION}

Eighty-four pollen types are established in honey samples. These types belong to 40 botanical families. The most important sources of pollen are plants from Asteraceae, Fabaceae and Rosaceae families. Dominant pollen types are Brassica napus ssp. oleifera, R. pseudacacia, $H$. annuus and Tilia spp. The most significant important minor pollen types are Salix spp. and Fraxinus sp.
Fourthy unifloral and 20 multifloral samples of honey were established on the botanical origin. The abundance of unifloral Black locust honey samples reflects the importance of this species in north-eastern Croatia. Black locust is invasive species and can be a threat to native flora but has a strong economic effect for beekeepers.

\section{ACKNOWLEDGEMENTS}

This study is part of an examination project No. IZIP-2014-43 supported by Josip Juraj Strossmayer University of Osijek.

\section{REFERENCES}

1. Alegro, A., Bogdanović, S., Brana, S., Jasprica, N., Katalinić, A., Kovačić, S., ...\& Vuković, N. (2010) Botanički važna područja. Prirodoslovno-matematički fakultet. Sveučilište u Zagrebu. Hrvatska. Školska knjiga.

2. Bucher, E., Kofler, V., Vorwohl, G., \& Zieger, E. (2004). DasPollenbild der Südtiroler Honige Biologisches Labor der Landesagentur fur Umwelz und Arbeitsschutz. Stuttgart. Deutschland.

3. Cabrerra-Ruiz, C., Montilla-Gomez, J., Guerra-Hernandez, E., \& Molins-Marin, J. L. (1997). Physico-chemical analysis of orange honeys sold in Spain. Bulletin Technique Apicole, 24, 63-70.

4. Coffey, M. F., \& Breen, J. (1997). Seasonal variation in pollen and nectar source of honey bees in Ireland. Journal of Apicultural Research, 36(2), 63-76. https:// doi.org/10.1080/00218839.1997.11100962

5. Čeksteryte, V., Kurtinaitiene, B., \& Balžekas, J. (2013). Pollen diversity in honey collected from Lithuania's protected landscape areas. Proceedings of the Estonian Academy of Sciences, 62(4), 277-282. https://doi. org/10.3176/proc.2013.4.08.

6. Farkas, A., \& Zajacz, E. (2007). Nectar production for the Hungarian honey industry. The European Journal of Plant Science and Biotechnology, 1(2), 125-151. http://www.globalsciencebooks.info/Online/GSBOnline/ images/0712/EJPSB_1(2)/EJPSB_1(2)125-1510.pdf

7. Gambon, N., Renzo, B., \& Frilli, F. (1995). The potential of beekeeping in the Upper Tagliamento Basin. LApe Nostra Amica, 17(5), 4-10.

8. Karabournioti, S., Thrasyvoulou, A., \& Eleftheriou, E. P. (2006). A model for predicting geographic origin of honey from the same floral source. Journal of Apicultural Research, 45(3), 117-124. https.//doi.org/10.1080/0021 8839.2006.11101329.

9. Kaya, Z., Binzet, R., \& Orcan, N. (2005). Pollen analysis of honeys from some regions in Turkey. Apiacta, 40, 10-15. http://www.apimondia.com/apiacta/articles/2005/kaya_1.pdf

10. Lazarova, M. A., Atanassova, J. R., \& Yurukova, L. D. (2010). Botanical origin and inorganic content of bee honey in Northeast Bulgaria (Shumen region). Phytologia Balcanica, 16(1), 131-135.

11. Louveaux, J., Maurizio, A., \& Vorwohl, G. (1978). Methods of melissopalynology. Bee World, 59(4), 139157. https://www.service-public.pf/dag/wp-content/ 
uploads/sites/28/2018/06/annexe3-article-methodemelissopalynology-Louveaux_etal1978.pdf

12. Ministry of Agriculture, Fisheries and Rural Development (2009). Regulations: unifloral honey quality. Official Gazette 122. https://narodne-novine.nn.hr/clanci/sluzbeni/2009 0793 2338.html

13. Pérez-Arquillué, C. (1986). Bromatological study of honey from Los Monegros: Palynological and protean amino acid analysis. Tes. D. Cie. Univ. Zaragoza.

14. Primorac, L., Bubalo, D., Kenjerič, D., Flanak, I., Perl Pirički, A., \& Mandić, M. L. (2008). Pollen spectrum and physicochemical characteristics of Croatian Mediterranean multifloral honey. Deutsche LebensmittelRundschau, 104(4),170-175. https://www.dlr-online. de/fileadmin/content/pdf/DLR Archiv/Index2008/ dlr_04_08.pdf\#page $=16$

15. Puusepp, L., \& Koff, T. (2014). Pollen analysis of honey from the Baltic region, Estonia. Grana, 53(1), 54-61. https://doi.org/10.1080/00173134.2013.850532.

16. Ramos, S. E., Perez, B. M., \& Ferreros, G. C. (1999). Pollen characterization of multifloral honeys from La Parma (Canary Islands). Grana, 38(6), 356-360. https:// doi.org/10.1080/00173130050136145

17. Sabo, M., Potočnjak, M., Banjari, I., \& Petrović, D. (2011). Pollen analysis of honeys from Varaždin County, Croatia. Turkish Journal of Botany, 35(5), 581-587. https://doi.org/ 10.3906/bot-1009-86.

18. Salonen, A., Ollikka, T., Grönlund, E., Ruottinen, L., \& Julkunen-Tiitto, R. (2009). Pollen analyses of honey from Finland. Grana, 48(4), 281-289. https://doi. org/10.1080/00173130903363550.

19. Silici, S., \& Gökceoglu, M. (2007). Pollen analysis of honeys from Mediterranean region of Anatolia. Grana, 46(1), 57-64. https://doi.org/ 10.1080/00173130601138783.

20. Shannon, C. E., \& Weaver, W. (1949). The mathematical theory of communication. University of Illinois. Press. Illinois. USA.
21. Sorkun, K., \& Yulug, N. (1985). Rize-lkizdere Yöresi ballarinin pollen analizi ve antimikrobil özellikleri. Doga Bilim Dergisi A2, 9, 118-123.

22. Štefanić, E., Štefanić, I., \& Šolić, M. E. (2005). Common indigobush and its significance for beekeeping in the Republic of Croatia. Bee World, 86(2), 42-43. https://doi. org/ 10.1080/0005772X.2005.11099652.

23. Štefanić, E., Zima, D., Rašić, S., \& Radović, V. (2012). Botanical origin of honey Pozega Valley. In M. Pospišil (Ed.), Proceedings $47^{\text {th }}$ Croatian and $7^{\text {th }}$ International Symposium on Agriculture, (pp. 629-633). Opatija, Croatia.

24. Terrab, A., Valdes Castrillon, B., \& Diez Dapena, M. J. (2001). Pollen analysis of honey from the Gharb region (NW Morocco). Grana, 40(4-5), 210-216. https://doi. org/10.1080/001731301317223231.

25. Valencia-Barrera, R. M., Herrero, B., \& Molnar, T. (2000). Pollen and organoleptic analysis of honeys in Leon Province (Spain). Grana, 39(2-3), 133-140. https://doi. org/10.1080/001731300300045283.

26. Von der Ohe, K., \& von der Ohe, W. (2003). Celle's mellisopalinological collection. Niedersächsisches Landesinstitut für Bienenkunde herzogin - Eleonore Allee 5. D-29221-Celle, CMS.

27. Von der Ohe, W., Persano Oddo, L., Piana, M. L., Morlot, M., \& Martin, P. (2004). Harmonized methods of melissopalynology. Apidologie, 35(1), 18-25.

28. Wroblewska, A., Warakomska, Z., \& Koter, M. (2006) Pollen analysis of bee products from the north-eastern Poland. Journal of Apicultural Science, 50(1), 71-83.

29. Zima, D., \& Štefanić, E. (2009). Florističke značajke suhih travnjaka Požeške kotline. Agronomski glasnik, 71(2): 141-150. http://oknobit.com/agronomsko.hr/casopisi/ agronomski_glasnik/Arhiva/2009/02/141_150_04_D_ Zima_i_sur_Floristicke_znacajke.pdf

\section{PELUDNA ANALIZA MEDA SJEVEROISTOČNE HRVATSKE}

\section{SAŽETAK}

$U$ istraživanju je analizirano 60 uzoraka meda s različitih područja sjeveroistočne Hrvatske na sadržaj i udio peludi. Ukupno je determinirana pelud 84 biljnih vrsta koje pripadaju u 40 porodica. Najzastupljenije su porodice u analiziranim uzorcima meda bile Asteraceae, Fabaceae i Rosaceae. Od analiziranih uzoraka meda, za 40 je uzoraka utvrđena uniflornost, dok ih je 20 svrstano u multiflorni med. Od uniflornih vrsta meda 26 je uzoraka deklarirano kao bagremov med, zatim 12 kao med od uljane repice te dva uzorka kao lipov med. Uzorci meda sadržavali su 9-25 vrsta peludi, a prevladavajuće vrste peludi bile su od biljaka iz porodice Brassicaceae i Robinia pseudacacia.

\section{Ključne riječi: melisopalinološka analiza, botaničko podrijetlo, med, sjeveroistočna Hrvatska}

(Received on 16 May 2018; accepted on 14 November 2018 - Primljeno 16. svibnja 2018.; prihvaćeno 14. studenoga 2018.) 